\title{
Mathematical Modeling of Linear Static and Dynamic Analysis for Pier Height Effect on the Structural Performance of Bridges Structures
}

\author{
Ali Fadhil Naser ${ }^{*}$, Hussam Ali Mohammed ${ }^{1}$, Ayad Ali Mohammed ${ }^{2}$ \\ ${ }^{1}$ Building and Construction Engineering Department, Al-Mussaib Technical College, Al-Furat Al-Awsat Technical University, \\ Babylon 51006, Iraq \\ ${ }^{2}$ Computer Center, Al-Mussaib Technical College, Al-Furat Al-Awsat Technical University, Babylon 51006, Iraq \\ Corresponding Author Email: com.ali3@atu.edu.iq
}

https://doi.org/10.18280/mmep.080415

Received: 20 April 2021

Accepted: 11 June 2021

\section{Keywords:}

bridge pier, linear static, dynamic, pier height, structural performance, moment, frequency

\begin{abstract}
The results of linear static analysis explained that the increasing of pier heights was leaded to rise the values of positive bending moment, tensile stresses, and downward vertical deflection. Whereas the compressive stresses and negative bending moment were decreased, indicating that the structural performance of bridge structure representing by stiffness, bearing capacity of structural members, and elasticity will decrease and the bridges structures will be damaged. Therefore, the bridges structures need safe design when using tall piers by adopting high quality materials such as high strength concrete, more steel reinforcement, more prestressed tendons, and increasing of cross section dimensions of girders and piers. The results of modal analysis show that the un-loaded dynamic frequency for three types of bridges models were decreased when the pier heights were increased, indicating that the stiffness of bridges structure was became low with higher pier height. According to response spectra and time history analysis results, the loaded dynamic frequency (vibration state) and dynamic displacement were increased when the pier heights were increased, showing that the bridge of structure will suffer from high vibration when the pier height was high. It can be concluded that from this study, the piers heights have significant effects on the static and dynamic structural performance of bridges structures under traffic loads.
\end{abstract}

\section{INTRODUCTION}

According to topography of the construction area, city, or traffic intersections types which need to construct bridges to cross the waterway and obstacles, or to reduce the traffic jam in intersections, the bridges designers need to use different heights of bridge piers. Therefore, piers heights are important factors in the design of bridge substructure.

A bridge structure is normally used in lifelines. They play a significant position in the economic activities of cities and they are one of the important elements of any transport road and rail network. If bridge structure was subjected to dynamic loads such as vehicles load with different speeds and seismic event, different levels of damages and failures will appear. The main parameters that eliminated the damages and failures are the intensity of dynamic and seismic loads, type of soil, spans length and number, types of superstructures and substructure, materials, number of piers, skew angle, and curvature. The pier height has important effect in the design of bridge structure which is subjected to dynamic loads $[1,2]$.

Substructure of bridges consists of some important parts which are include foundations, piers, pier caps, and abutments. The types of bridge substructure are selected during the first round of design stage of the bridge design depending on different types of factors such as kind of natural soil, skew angle, kind of superstructure, locality of a roadway and railway tracks, cost of construction. The kind of bridge foundations is depended on a number of factors such as soil type below the substructure components, total bridge length (numbers of spans), kind of bridge, nearness to water [3-5].

Substructure components (abutments and piers) are used to carry and support bridge superstructures parts such as bearings, beams or girders, deck, and pavement layers. Mostly, abutments and piers are constructed and made by using reinforced concrete (normal or prestressed). The favored information for connecting the superstructure to the substructure are dependent on the geometry and bridge kind [6, 7].

Piers (column) of bridge are structures, which give vertical supports for spans of bridge at intermediate points to resist horizontal loads and to transfer the different types of loads such as dead loads of superstructure, construction loads, traffic loads to the foundations which are acting on the bridge structure. Additionally, piers are designed to resist high lateral loads caused by seismic actions. Any disaster in a pier with a critical position causes a disaster in that position and all the nearby structural members and it can lead to the complete failure of the structure [8-10].

Piers are elevated structure and they are constructed by using bricks or stone masonry. The piers are supported on foundation like spread footings, piles, wells or caissons. The superstructures comprising the slab or beams transmit the reactions to the piers and abutments through the bridge bearings and bed locks $[11,12]$.

The shape of a pier depends on some factors such as the type, size and dimensions of the superstructure. There are some 
types of piers which they are used to support structure of bridges. When bridges cross a roadway or railway traffic, the using of piers are multi-column or hammerhead piers. The structure of piers can be solid, square, rectangular, circular, trestle and hammer-head types. Solid piers are of masonry or mass concrete. Cellular, trestle and hammer-head types are constructed in reinforced concrete $[13,14]$.

Piers can be named as tall pier (high pier) when the height of pier structure more than $30 \mathrm{~m}$. According to development of world economy, there are many bridges have been constructed in the rugged topography which are using piers has height more than $40 \mathrm{~m}$ to span across deep valleys. When using tall piers in the construction of bridges, there are two types of higher mode influences. The first is the results from the irregularity of the structure system of bridges and the second comes from the tall piers themselves $[15,16]$.

There are a large variety of piers kinds which are used in the construction of bridges structures. The horizontal longitudinal and transverses spacing between piers, and pier height depends on the types of bridge superstructure, the spacing of superstructure girder, the column size, and the aesthetic requirements [17].

Tang and Li studied the effect of pier height on the spatial vibration of the bridge for train system. They selected four multi-span simply supported bridge with different pier heights. They concluded that the natural frequency (unloaded case) was increased with decreasing of pier height. The dynamic coefficients in the middle of span differ with the pier height at maximum speed of train. The dynamic displacements were increased when the pier height increased. The vertical accelerations in the top of pier were higher when the speed of train increased [17].

Agrawal et al. investigated the effect of vehicles loads with different speeds on a three spans steel girder bridge structure with reinforced concrete piers by using LS-DYNA, including a connection between seismic and shock resistance of bridge piers. They presented a comparative study between static load prescribed by AASHTO Guide Specifications and dynamic shocks loads which was investigated during theoretical analysis [18].

In general, the objectives of dynamic analysis (response spectra, modal and time history analysis) are to presents a correct evaluation of expected structural reactions for a given seismic event or movement of vehicles on the bridge structure, to give a nominal compute of expected answers, which will make sure sufficient behaviour of the structure, and to make sure that an easy and straight load route is provided for each frame [19].

There are several studies investigated the dynamic behaviours of bridges structure with different pier heights under seismic event without considering the effect of vehicles loads such as the literatures [20-27].

The purpose of this study is to investigate the effects of piers height on the linear static dynamic responses under vehicles loads by using linear static, response spectra, and time history analysis methods for three different types of bridges structure.

\section{GEOMETRY, PROPERTIES, AND LOADS OF BRIDGES MODELS}

In this study, three types of bridges structures are selected to study the effects of different piers heights on the static and dynamic responses by adopting response spectra, modal and time history analysis. These types of bridges structures are precast concrete of four girders $\mathrm{U}$ shape, prestressed concrete box girder with three cells, and composite bridge (steel I girders under concrete deck). SAP2000 is used to create threedimension finite element models. Pier type is a solid rectangular shape concrete and they have heights which range between $8 \mathrm{~m}$ and $60 \mathrm{~m}$ dividing by $4 \mathrm{~m}$. All bridges models have same total length is $(200 \mathrm{~m})$, width $(11 \mathrm{~m})$, and each span length is $20 \mathrm{~m}$ and number of spans is 10 . Table 1 lists the piers heights and Figures 1, 2, and 3 show the types of bridges models with different heights of piers. Models have pier heights $8 \mathrm{~m}, 36 \mathrm{~m}$, and $60 \mathrm{~m}$ are selected to show in the figures for all three types of bridges structures.

The properties of materials are similar for all types of bridges models, piers, and piers cap. These materials include concrete, prestressed tendons, and steel. The grade of concrete is C-40 and the weight per unit volume is $23.56 \mathrm{kN} / \mathrm{m}^{3}$. The type of prestressed tendons is $\mathrm{A} 416 \mathrm{Gr} 270$ with weight per unit volume is $76.97 \mathrm{kN} / \mathrm{m}^{3}$ and minimum yield stress and minimum tensile stress are $1689.9 \mathrm{MPa}$ and $1861.5 \mathrm{MPa}$ respectively.

Table 1. Pier heights for bridges model

\begin{tabular}{cc}
\hline Model No. & Pier Height $(\mathbf{m})$ \\
\hline 1 & 8 \\
2 & 12 \\
3 & 16 \\
4 & 20 \\
5 & 24 \\
6 & 28 \\
7 & 32 \\
8 & 36 \\
9 & 40 \\
10 & 44 \\
11 & 48 \\
12 & 52 \\
13 & 56 \\
14 & 60 \\
\hline
\end{tabular}

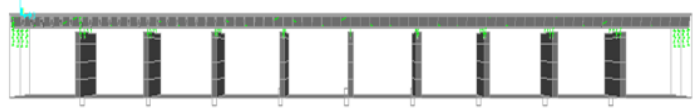

(a) Elevation view

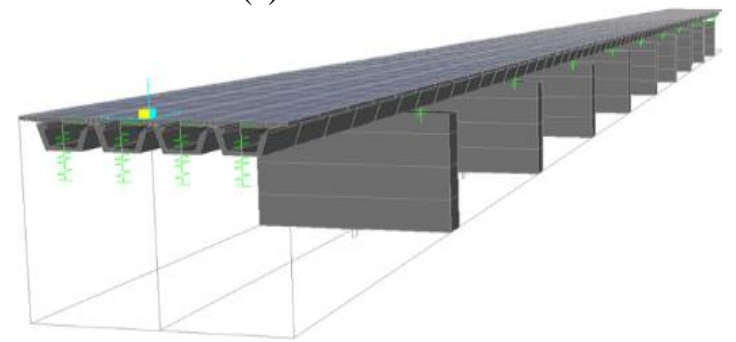

(b) Pier height $(8 \mathrm{~m})$

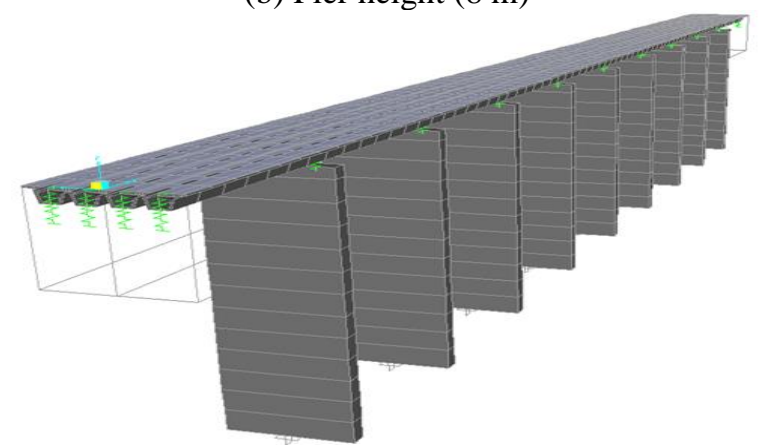

(c) Pier height (36 m) 


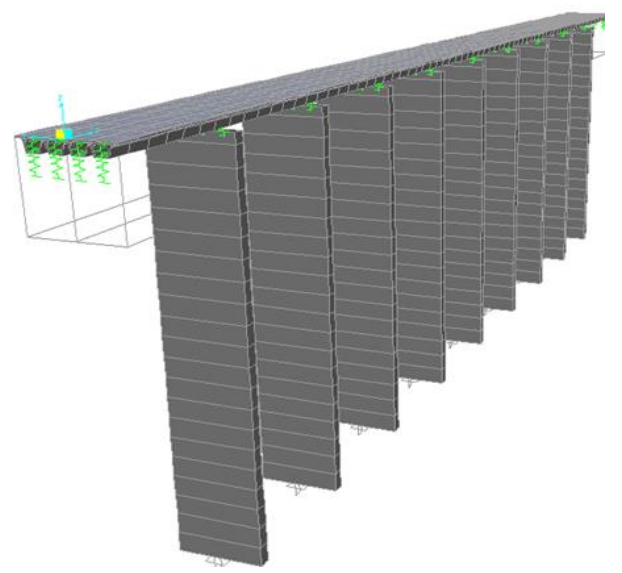

(d) Pier height $(60 \mathrm{~m})$

Figure 1. U shape girder bridge models

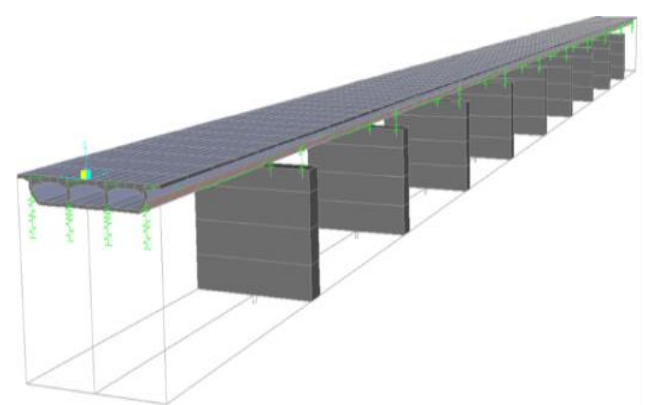

(a) Pier height (8 m)

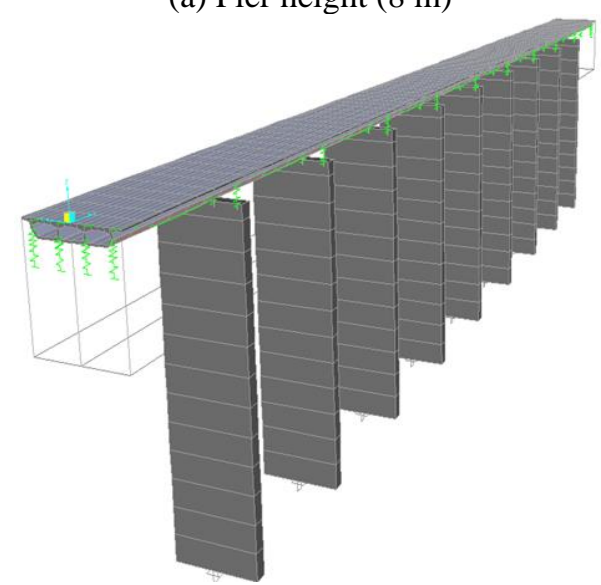

(b) Pier height $(36 \mathrm{~m})$

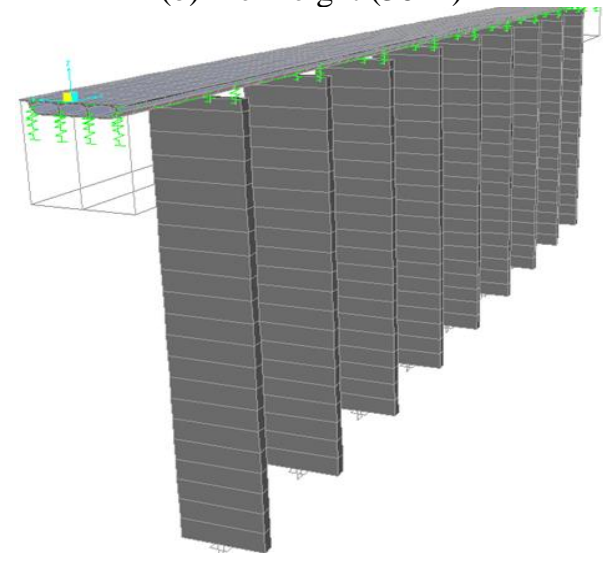

(c) Pier height $(60 \mathrm{~m})$

Figure 2. Box girder bridge models

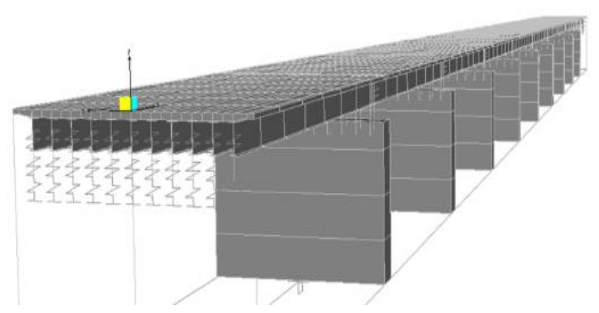

(a) Pier height $(8 \mathrm{~m})$

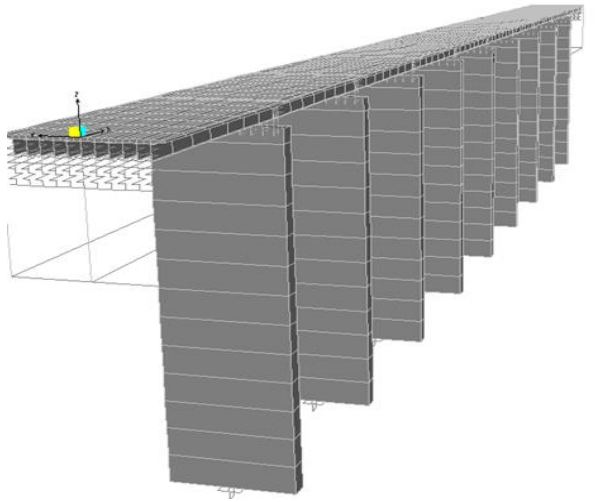

(b) Pier height $(36 \mathrm{~m})$

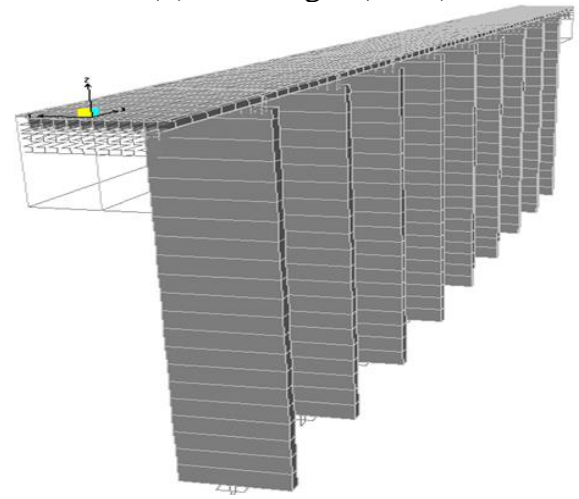

(c) Pier height $(60 \mathrm{~m})$

Figure 3. Composite bridge models

For linear static analysis, the loads combination consists of dead load of structure, live load of traffic, pavement layer weight, pedestrian loads on sidewalk, prestressed tendons load, and temperature loads. The dynamic load is used standard vehicle type HL-93M. It is a type of designed vehicular load proposed by AASHTO in 1993 which is used as the design load for highway structures in USA and other countries where AASHTO code is followed. Figure 4 shows HL-93M Design vehicle AASHTO.

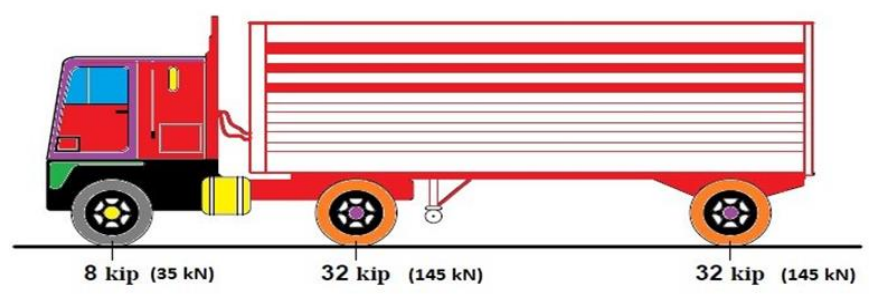

(a) Side view 


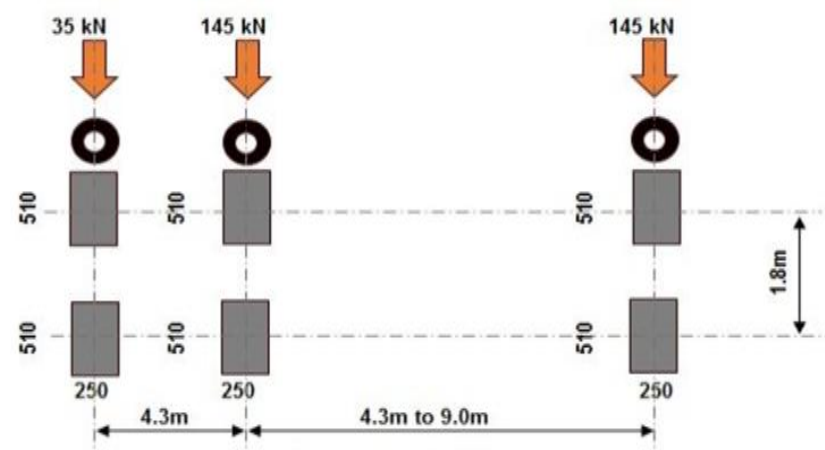

(b) Plan view

Figure 4. HL-93M Design vehicle AASHTO [27]

\section{LINEAR STATIC ANALYSIS}

Linear static analysis is an important method to analyze bridges structures. When compared with non-linear analysis method, linear analysis is a proficient method to determine static parameters of bridges structures as it assumes the structure to perform in an elastic mode. Generally, the essential theory of linear static is that the behavior of bridge structure is linear according Hook law and the loads are static without movement. For important structures such as bridges, linear static analysis, dynamic analysis needs to apply with static analysis. Static analysis can be carried out by hand or using a computer program such as ANSYS, SAP2000, MIDAS, CSI bridge and others engineering programs. The finite element method is a right theoretical method to find solutions of differential equations for the structural engineering applications, spatially in bridges analysis [28-33]. In this study, three static responses are used to find the effects of pier heights on the structural performance of three types of bridges structure. These responses include bending moment, stresses, and vertical deflection. CSI bridge Ver. 20 is used to create bridges models and analyzing process.

\subsection{Results of bending moment}

Bending moment takes place when the structure is subjected to a force at a given distance away from a point of position which is causing a bending effect. When structure has not enough stiffness and bearing capacity, the bending moment will cause to rotate about a certain point. Static responses values depend on the bending moment values. When bending moment increased, leading to increasing in stresses and vertical deflection values [34].

Figure 5 illustrates the magnitudes of positive bending moment for precast concrete of four girders U shape models, prestressed concrete box girder with three cells models, and composite bridge (steel I girders under concrete deck) models. Prestressed concrete box girder bridge models have the higher values of positive bending moment than others types of bridges models. Therefore, the values of tensile stresses and vertical deflection will increase for this type of bridge. The results of analysis shows that the values of positive bending moment increase when the heights of piers structures are increasing. The maximum value of positive bending moment for all three types of bridges models appears within No. 14 (piers height is $60 \mathrm{~m}$ ) which are 1,6421 kN.m, 21,491 kN.m, and $10,367 \mathrm{kN} . \mathrm{m}$ for precast concrete of four girders $U$ shape models, prestressed concrete box girder bridge models, and composite bridge models respectively.

The results of negative bending moment can be seen that in Figure 6 . The values of negative bending moment decrease with increasing of piers heights for all types of bridges models. The lower values of negative bending moment for precast concrete of four girders U shape models, prestressed concrete box girder bridge models, and composite bridge models are 16,276 kN.m, 18,563 kN.m, and 9,053 kN.m respectively.

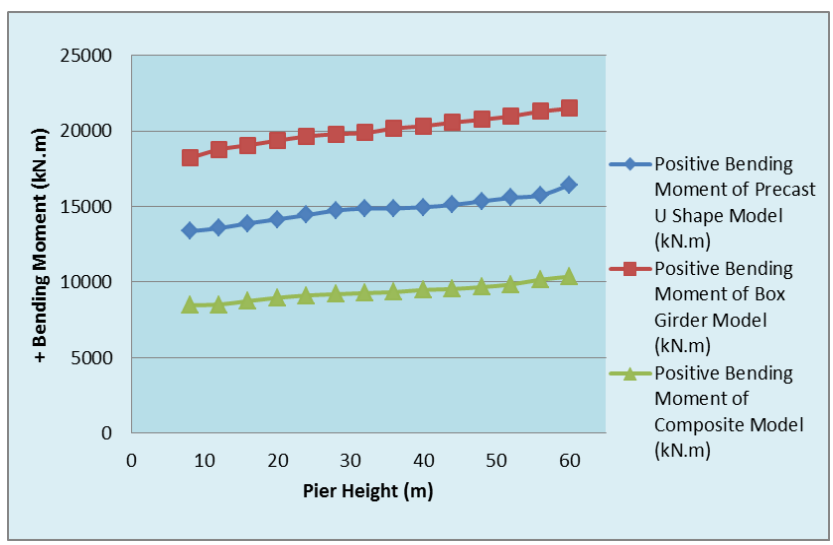

Figure 5. Magnitudes of positive bending moment

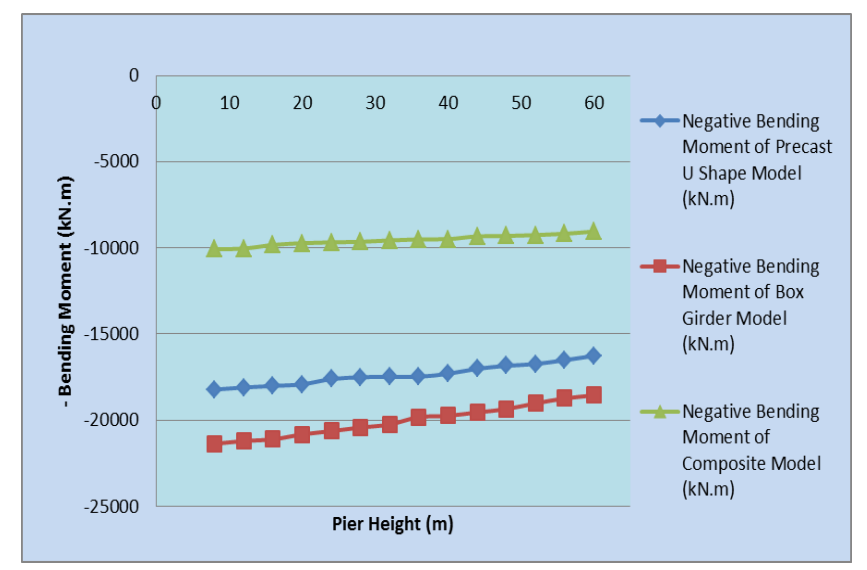

Figure 6. Magnitudes of negative bending moment

\subsection{Results of tensile and compression Stresses}

Stress is a physical magnitude that expresses the internal forces that neighboring particles of a continuous material apply on each other [35]. Stress can be defined as the resistance of structure to external force and it is equal to force (fundamental physical quantity) per area (geometrical quantity) [36]. Generally, there are two types of stresses such as tensile stress and compressive stress. These types are important and they have significant effects on the structural performance of concrete and steel structures because of there is relationship between stresses and appears cracks in structures. Tensile stress occurs due to stretching or tensile forces and it is dependable for the elongation of the structure along the axis of the applied load. Compressive stress can be defined as the stress that results in the compression of the material and it occurs due to a compressive force [35-37].

The results of linear static analysis shows that the values of tensile stresses for all three types of bridges models increases with increasing of piers heights, indicating that the piers heights have significant effects on the appearing of cracks within bridges models that have tensile stresses more than 
allowable stresses. Figure 7 shows the values of tensile stresses and box girder bridge models have higher values of tensile stresses than others two types of bridges. Model No. 14 has maximum values of tensile stress which is $4.78 \mathrm{MPa}$. For precast concrete $U$ shape models and composite bridge models, the higher values of tensile stresses also appear within model No. 14 (60 m pier heights) and they are $3.76 \mathrm{MPa}$ and 3.59 $\mathrm{MPa}$ respectively. The magnitudes of compressive stresses decreases when pier heights are decreased. Therefore, the minimum magnitudes of compressive stresses are $12.39 \mathrm{MPa}$, 9.03 $\mathrm{MPa}$, and 16.17 MPa for precast concrete U shape models, prestressed concrete box girder models, and composite models within model No. 14 (60 m pier heights) respectively. Figure 8 shows the values of compressive stresses.

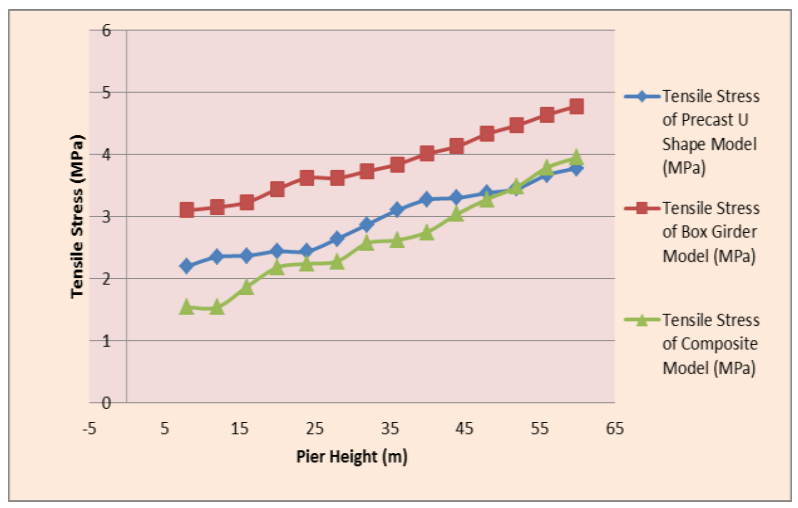

Figure 7. Magnitudes of tensile stresses

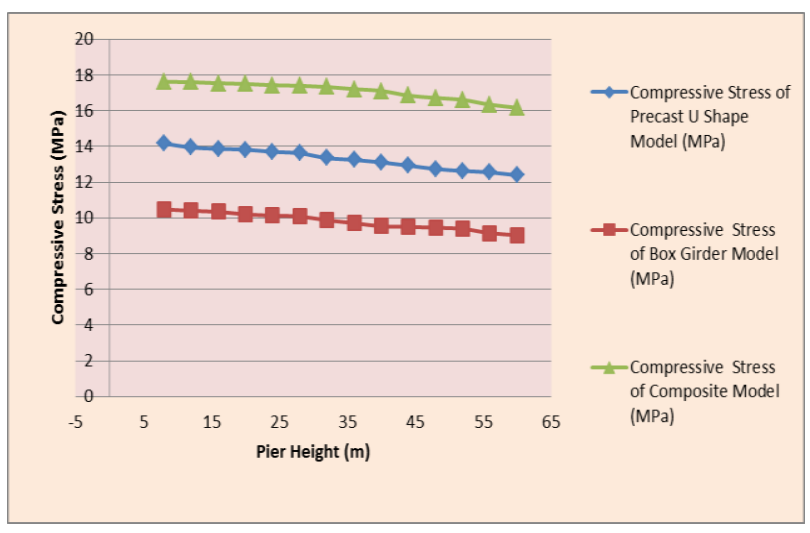

Figure 8. Magnitudes of compressive stresses

\subsection{Results of vertical deflection}

Vertical deflection of civil structure such as bridge means the movement or displacement of a beam, girder, or node from its original location due to the external loads and dead loafs (weight of structure) being applied to the structure part. Therefore, vertical deflection can be defined as the vertical distance between a point from the un-deformed axis of a structure and the same point which lies on the deformed axis. $[34,38]$

Figure 9 illustrates the vertical deflection values for three types of bridges models which are selected in this study. From this figure it can be seen that prestressed concrete box girder bridge models give higher values of vertical deflection and composite bridge models produce lower values of vertical deflection. When the pier heights of bridges structures are increased, the values of vertical deflection are increased, Therefore, the bridge structure may be subjected to damage.
For precast concrete $\mathrm{U}$ shape bridge models, the minimum value of vertical deflection is $13 \mathrm{~mm}$ within model No. $1(8 \mathrm{~m}$ pier height) and the maximum value is $20 \mathrm{~mm}$ within model No. 14 (60 m pier height). The higher value of vertical deflection for prestressed concrete box girder bridge models is $27 \mathrm{~mm}$ within model No. 14 (60 m pier height) and the lower value is $17 \mathrm{~mm}$ within model No. 1 ( $8 \mathrm{~m}$ pier height). Composite bridge model appears minimum value within model No. 1 ( $8 \mathrm{~m}$ pier height) which is $8 \mathrm{~mm}$ and maximum value is $17 \mathrm{~mm}$ within model No. 14 (60 m pier height).

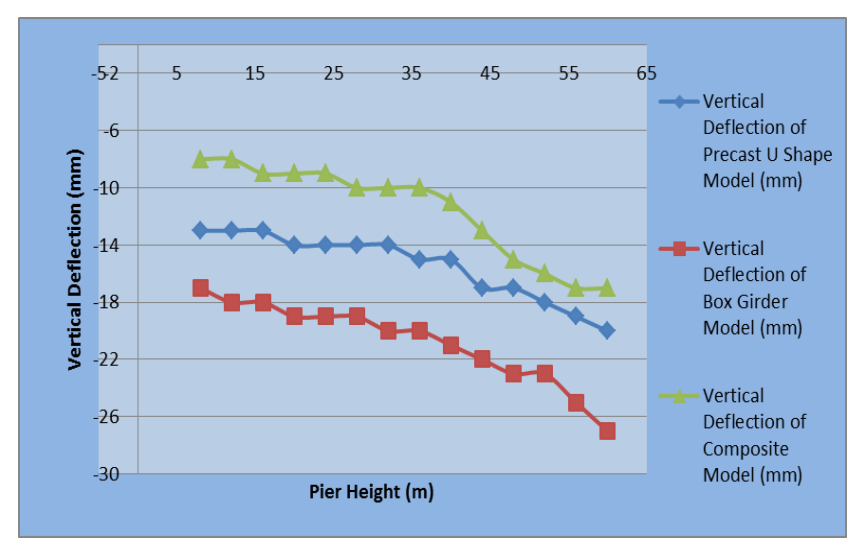

Figure 9. Magnitudes of vertical deflection

\section{MODAL, RESPONSE SPECTRA, AND TIME HISTORY ANALYSIS}

The purpose of modal analysis is to transfer fully coupled problem of $\mathrm{N}$ degrees of freedom to $\mathrm{N}$ uncoupled singledegree-of freedom (SDOF) problems that can be solved individually. The essential properties of modal analysis can be accurately captured of the response if the small number of modes are considered. Therefore, the number of modes depends on the applied load and on the response factors were examined. This method is used to determine the natural frequency of bridge structure (without external live loads). Response spectrum and time history analysis is a method usually used for the design of structures. It presents for linear or nonlinear assessment of dynamic response under live loads Practically, the method is an overview of modal analysis. The objective of this method is to supply quick calculations of the peak response without the need to carry out response history analysis. This method is used to find dynamic vibration frequency, the dynamic displacement, velocity and acceleration (dead load with live loads) [39-42].

\subsection{Results of un-loaded dynamic frequency}

Un-loaded dynamic frequency is measured vertical direction (critical stage) by using modal analysis to determine modes shapes of displacement in three dimensions of structure (longitudinal, transverse, and vertical) under dead load only (weight of structure) without external loads. In this stage of analysis, natural vibration of structure will be measured. Figure 10 shows the results of modal analysis for three types of bridges models with different pier heights. From this figure it can be noted that the un-loaded dynamic frequency for three types of bridges models is decreased when the pier heights are increased, indicating that the stiffness of bridges structure is became low with higher pier height. 


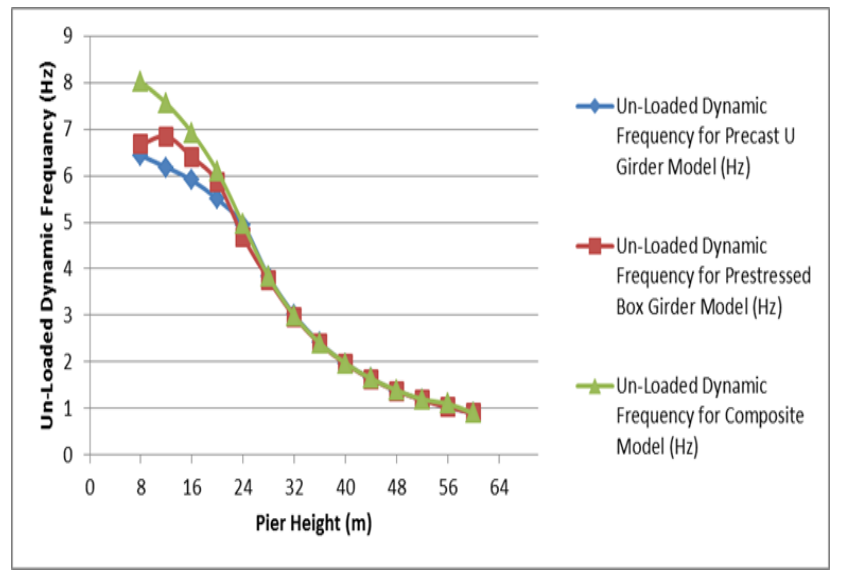

Figure 10. Results of modal analysis of un-loaded dynamic frequency for three types of bridges models with different pier heights

\subsection{Results of loaded dynamic frequency}

Loaded dynamic frequency is determined in vertical direction (critical stage) by adopting response spectra and time history analysis under live loads (vehicles loads). Response spectra is the elastic dynamic analysis method and it involves the determination of the maximum values of displacements and forces in each mode of vibration. Time history analysis determines the responses of structure which is applied to dynamic loads [43]. The values of loaded dynamic frequency can be shown in Figure 11. Models with pier height $8 \mathrm{~m}$ appear lower values of loaded dynamic frequency, which are equal to $4.38 \mathrm{~Hz}, 3.89 \mathrm{~Hz}$, and $5.59 \mathrm{~Hz}$ for precast concrete of four girders U shape, prestressed concrete box girder with three cells, and composite bridge (steel I girders under concrete deck) respectively, than models with pier height $60 \mathrm{~m}$ which are equal to $6.97 \mathrm{~Hz}, 6.92 \mathrm{~Hz}$, and $7.44 \mathrm{~Hz}$ for precast concrete of four girders $U$ shape, prestressed concrete box girder with three cells, and composite bridge (steel I girders under concrete deck) respectively. It can be concluded that the loaded dynamic frequency (vibration state) is increased when the pier heights are increased, indicating that the bridge of structure will suffer from high vibration when the pier height is high.

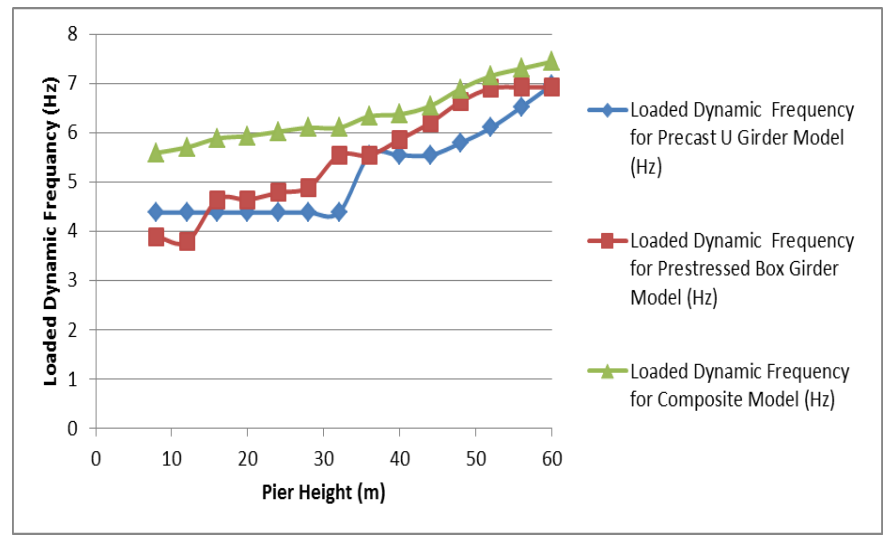

Figure 11. Values of loaded dynamic frequency for three types of bridges models with different pier heights

According to comparative curves in Figure 12, Figure 13, and Figure 14, the bridges structures appear higher values of un-loaded dynamic frequency than loaded dynamic frequency within the first five models for $U$ shape structures, within the first four models of box girder structure and composite model, indicating that these models have higher stiffness than others. The models after pier height $28 \mathrm{~m}$ appear lower values of unloaded dynamic frequency than loaded dynamic frequency for three types of bridges models, meaning that these models have lower stiffness and elasticity. Therefore, the bridge structure with high pier heights need to redesign by increasing the cross sections of girders and piers, reinforcement, high strength concrete and steel, construction of diaphragms in transverse direction.

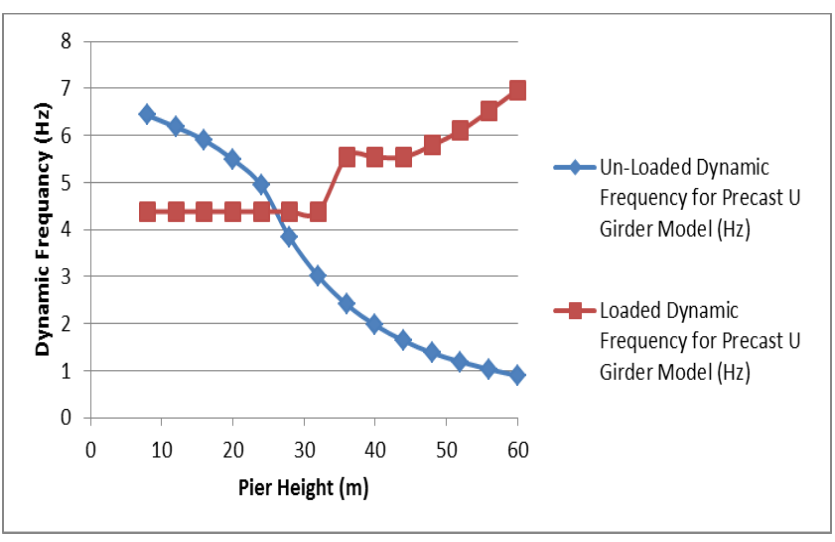

Figure 12. Comparative curves between loaded and unloaded dynamic frequency for $\mathrm{U}$ shape model

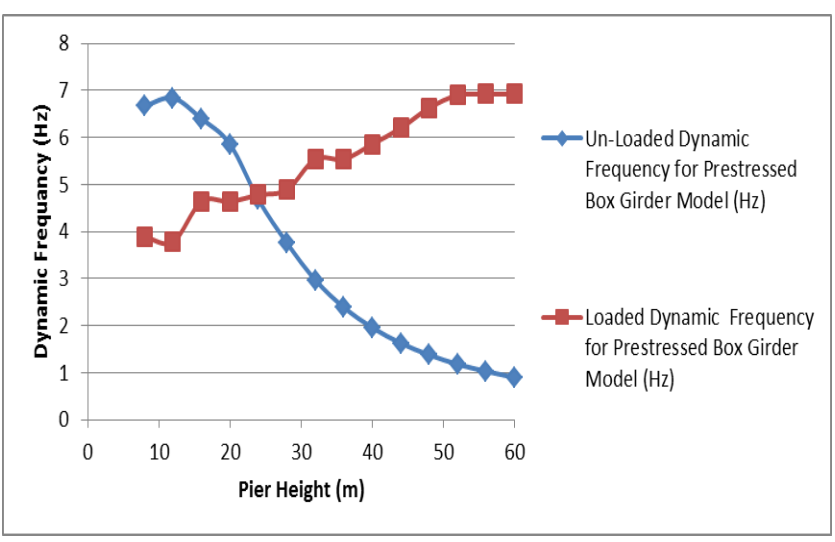

Figure 13. Comparative curves between loaded and unloaded dynamic frequency for box girder model

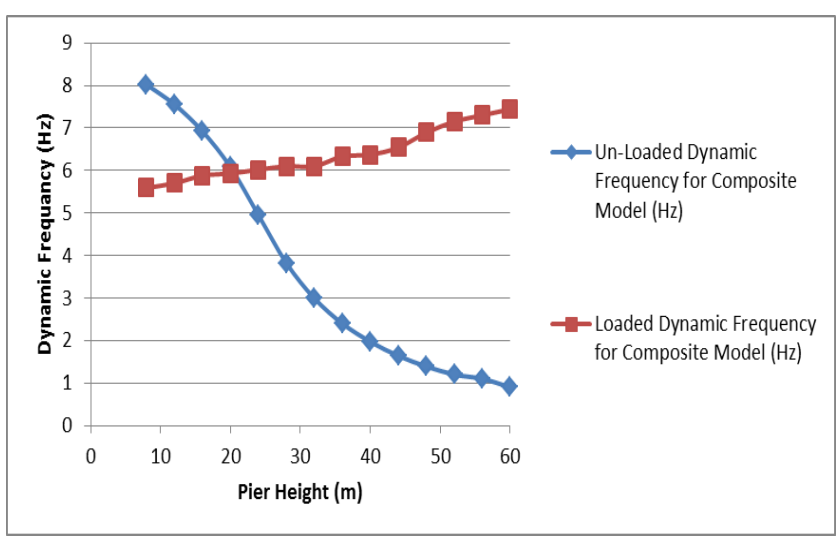

Figure 14. Comparative curves between loaded and unloaded dynamic frequency for composite model 


\subsection{Results of loaded dynamic displacement}

Loaded dynamic displacement is important factor in the dynamic analysis because it measures the vertical movement of bridge structure in upward and downward direction under traffic loads. Figure 15 gives the results of loaded dynamic displacement according to spectra and time history analysis. It can be seen that the values of displacement are increased when the pier heights are increased due to high vibration state in high pier heights. Models with pier height $8 \mathrm{~m}$ have displacement value are equal to $2.26 \mathrm{~mm}, 2.91 \mathrm{~mm}$, and $1.60 \mathrm{~mm}$ for precast concrete of four girders $U$ shape, prestressed concrete box girder with three cells, and composite bridge (steel I girders under concrete deck) respectively. Whereas, models with pier height $60 \mathrm{~m}$ give displacement value higher than others models and equal to $4.46 \mathrm{~mm}, 5.18 \mathrm{~mm}$, and $3.71 \mathrm{~mm}$ for precast concrete of four girders $U$ shape, prestressed concrete box girder with three cells, and composite bridge (steel I girders under concrete deck) respectively.

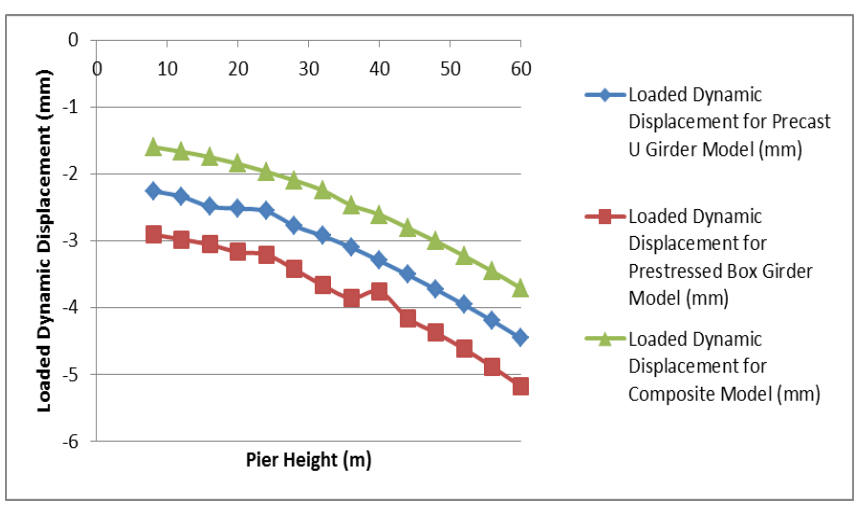

Figure 15. Results of loaded dynamic displacement for three types of bridges models with different pier heights

\section{CONCLUSIONS}

1) Three types of bridges structures are selected to study the effects of different piers heights on the static structural performance. These types of bridges structures are precast concrete of four girders $U$ shape, prestressed concrete box girder with three cells, and composite bridge (steel I girders under concrete deck). The piers heights are chosen to range between $8 \mathrm{~m}$ and $60 \mathrm{~m}$ dividing by $4 \mathrm{~m}$.

2) There are three static responses are used to find the effects of pier heights on the structural performance of three types of bridges structure. These responses include bending moment, stresses, and vertical deflection. CSI bridge is used to create bridges models and analyzing process.

3) The results of bending moment analysis show that the values of positive bending moment increase when the heights of piers structures are increasing. The maximum value of positive bending moment for all three types of bridges models appears within No. 14 (piers height is $60 \mathrm{~m}$ ) which are 16,421 kN.m, 21,491 kN.m, and 10,367 kN.m for precast concrete of four girders $U$ shape models, prestressed concrete box girder bridge models, and composite bridge models respectively. The values of negative bending moment decrease with increasing of piers heights for all types of bridges models. The lower values of negative bending moment for precast concrete of four girders $U$ shape models, prestressed concrete box girder bridge models, and composite bridge models are 16,276 kN.m,
18,563 kN.m, and 9,053 kN.m respectively.

4) The results of stresses shown that the values of tensile stresses for all three types of bridges models increases with increasing of piers heights. The maximum value of tensile stress for all three types of bridges models appears within model No. 14 (piers height is $60 \mathrm{~m}$ ) which are $3.76 \mathrm{MPa}, 4.78$ $\mathrm{MPa}$, and $3.59 \mathrm{MPa}$ for precast concrete of four girders $\mathrm{U}$ shape models, prestressed concrete box girder bridge models, and composite bridge models respectively.

5) Prestressed concrete box girder bridge models give higher values of vertical deflection and composite bridge models produce lower values of vertical deflection. The higher value of vertical deflection for prestressed concrete box girder bridge models is $27 \mathrm{~mm}$ within model No. 14 (60 m pier height). For precast concrete $U$ shape bridge models, the maximum value is $20 \mathrm{~mm}$ within model No. 14 (60 m pier height) and the maximum value of composite models is $17 \mathrm{~mm}$ within model No. 14 (60 m pier height).

6) The results of modal analysis shown that the unloaded dynamic frequency for three types of bridges models is decreased when the pier heights are increased, indicating that the stiffness of bridges structure is became low with higher pier height.

7) According to response spectra and time history analysis results, the loaded dynamic frequency (vibration state) is increased when the pier heights are increased, indicating that the bridge of structure will suffer from high vibration when the pier height is high.

8) Dynamic displacement analysis output shown that the values of loaded dynamic displacement are increased when the pier heights are increased due to high vibration state in high pier heights.

9) In general, the stiffness, elasticity, bearing capacity, and dynamic resistance are decreased when the pier heights are increased. Therefore, the bridge structure with high pier heights need to redesign by increasing the cross sections of girders and piers, reinforcement, high strength concrete and steel, construction of diaphragms in transverse direction.

\section{REFERENCES}

[1] Djemai, M., Bensaibi, M., Halfaya, F. (2019). The effect of type and height of piers on the seismic behavior of reinforced concrete bridges. International Journal of Engineering Research in Africa, 41: 79-87. https://doi.org/10.4028/www.scientific.net/JERA.41.79

[2] Tamanani, M., Gian, Y., Ayoub, A. (2016). Evaluation of code criteria for bridges with unequal pier heights. Bull Earthquake Engineering, 14: 3151-3174. https://doi.org/10.1007/s10518-016-9941-4

[3] Ali, F. (2018). Optimum design of vertical steel tendons profile layout of post-tensioning concrete bridges: FEM static analysis. ARPN Journal of Engineering and Applied Sciences, 13(23): 9244-9256.

[4] Department of Transportation. (2019). Substructure Guidelines.

http://www.dot.state.mn.us/stateaid/bridge/docs/substru cture-guidelines.pdf.

[5] WSDOT Bridge Design Manual. (2019). Substructure Design, Chapter 7.

[6] MnDOT LRDF Bridge Design Manual (BDM). (2016). Abutments, piers, and walls, Section I.

[7] Prabu, M., Vijayasarathy, R. (2016). Design and analysis 
of sub-structure of bridge-A review. International Journal of Engineering and Management Research, 6(5): 221-225.

[8] Jinrong, W. (2000). Piers and Columns, Bridge Engineering Handbook, Ed. Wai-Fah Chen and Lian Duan, Boca Raton: CRC Press.

[9] Ali, F. (2016). Effect of piers shape on the dynamic structural responses of prestressed concrete bridge: Part II. Journal of Babylon University/Engineering Sciences, 1(24): 14-25.

[10] Al-Hazragi, A., Lateef, A. (2021). Behaviour of uniaxial reinforced concrete columns strengthened with ultrahigh performance concrete and fiber reinforced polymers. Tikrit Journal of Engineering Sciences, 28(2): 54-72.

[11] Amit, K., Kulkarni, M. (2018). Parametric study of bridge piers. International Research Journal of Engineering and Technology, 5(1): 656-660.

[12] Neenu, A. (2020). Basic Components and Parts of Bridge Structures:

Substructure. https://theconstructor.org/structures/components-ofbridges-concrete-steel/17806/.

[13] Mark, R. (2020). Substructure maintenance procedures. In: FHWA Bridge Maintenance, Bridge Maintenance Training Reference Manual, Continuing Education and Development, Inc. https://www.cedengineering.com/userfiles/FHWA\%20 Bridge\%20Maintenance\%20Substructure\%20R1.pdf.

[14] Rashmi, R., Itti, S. (2013). Study on RCC bridge pier using ANSYS. International Journal of Engineering and Innovative Technology, 3(2): 149-152.

[15] Dhwani, M., Patel, U. (2016). Analysis of tall pier bridges. International Journal of Science Technology \& Engineering, 2(11): 255-257.

[16] Chen, X., Li, J., Guan, Z. (2016). Effects of higher modes on tall piers. In IABSE Symposium Report, International Association for Bridge and Structural Engineering. https://www.researchgate.net/publication/317759221_S eismic_Performance_of_Tall_Piers_Influenced_by_Hig her-mode_Effects_of_Piers.

[17] Tang, Q., Li, X. (2019). Influence of pier heights on spatial vibration of the train-bridge system. In Proceedings of the 2019 World Transport Convention, Beijing, China.

[18] Agrawal, A., Liu, G., Alampalli, S. (2013). Effects of truck impacts on bridge piers. Advanced Materials Research, $\quad$ 639-640: 13-25. https://doi.org/10.4028/www.scientific.net/AMR.639640.13

[19] Mehta, B. (2008). Basic methods of analysis for bridges. https://www.sefindia.org/?q=system/files/BRIDGES2.pdf.

[20] Abbasi, M., Zakeri, B., Amiri, G. (2015). Probabilistic seismic assessment of multiframe concrete box-girder bridges with unequal-height piers. Journal of Performance of Constructed Facilities, 30(2): 1-9. https://doi.org/10.1061/(ASCE)CF.1943-5509.0000753

[21] Mander, J. (1984). Seismic design of bridge piers. Ph.D dissertation, University of Canterbury, New Zealand.

[22] Guo, W., Hu, Y., Liu, H., Bu, D. (2019). Seismic performance evaluation of typical piers of China's highspeed railway bridge line using pushover analysis. Mathematical Problems in Engineering, 2019: 9514769. https://doi.org/10.1155/2019/9514769

[23] Patel, D., Parekh, U. (2016). Analysis of tall pier bridges.
International Journal of Science Technology \& Engineering, 2(11): 255-257.

[24] Zheng, Q., Liu, W. (2010). Seismic design of high pier for mountain bridges. APRN Journal of Engineering and applied sciences, 5(9): 58-63.

[25] Kulkarni, R., Adhikary, S., Singh, Y., Sengupta, A. (2014). Seismic performance of a bridge with tall piers. In Proceedings of the Institution of Civil Engineers, Bridge Engineering, 169(1): 67-75. https://doi.org/10.1680/bren.14.00027

[26] Hasan, H., Abdul Rahman, A., Ameen, H. (2012). Finite element analysis of reinforced concrete bridge pier subjected to seismic loading. American Journal of Scientific and Industrial Research, 3(2): 94-98, https://doi.org/10.5251/ajsir.2012.3.2.94.98

[27] Civil Engineering Organization. (2016). HL-93 AASHTO Vehicular Live Loading, Truck Tandem, Design Lane Load. https://engineeringcivil.org/articles/bridge/hl-93-aashtovehicular-live-loading-truck-tandem-design-lane-load/.

[28] Hussam A., Ali, F. (2020). Mathematical assessment of vehicles types and loads influences on the structural performance parameters of concrete and steel bridges. Journal of Engineering Science and Technology, 15(2): 1254-1266.

[29] Ali, F. (2017). Three-dimensional analysis of girder cross-section shapes effects on static properties of bridges models. Journal of Al-Qadisiyah for Engineering Science, $\quad$ 10(3): 244-258. http://qu.edu.iq/journaleng/index.php/JQES/article/view 1282.

[30] CSI Computer \&Structures Inc. (2010). Introduction to SAP2000/Bridge, Berkeley, California, USA.

[31] Mattias, G. (2012). Structural analysis and design of concrete bridges. Master Thesis. Department of Civil and Environmental Engineering Division of Structural Engineering Concrete Structures, Chalmers University of Technology, Sweden.

[32] Paulo, B. (2011). Types of analysis: Linear static, linear dynamic and nonlinear static. Institute for Sustainability and Innovation in Structural Engineering.

[33] Gabriel, R. (2018). Linear static analysis. https://www.midasoft.com/mechanical-blog-1/linearstatic-analysis.

[34] https://skyciv.com/docs/tutorials/beam-tutorials/whatis-deflection/.

[35] https://en.wikipedia.org/wiki/Stress_(mechanics)\#cite_n ote-Chen-3.

[36] Wai-Fah, C., Da-Jian, H. (2007). Plasticity for Structural Engineers. J. Ross Publishing ISBN 1-932159-75-4.

[37] https://byjus.com/physics/tensile-stress/.

[38] http://smat.info/content/Chankov/Castigliano $\% 27 \mathrm{~s} \% 20$ Theorem\%20-\%20Example\%201\%20-\%20Deflection.p df.

[39] Fragiadakis, M. (2013). Response spectrum analysis of structures subjected to seismic actions. Encyclopedia of Earthquake Engineering. Springer, Berlin, Heidelberg. https://doi.org/10.1007/978-3-642-36197-5_133-1

[40] Chopra, A. (2000). Dynamics of structures: Theory and applications to earthquake engineering. 2nd edn. Prentice Hall, Englewood Cliffs.

[41] https://en.wikipedia.org/wiki/Response_spectrum.

[42] https://wiki.csiamerica.com/display/kb.

[43] Chandrakar, P., Bokare, P.S. (2017). A review- 
comparison between response spectrum method and time history method for dynamic analysis of multistoried building. International Journal of Science and Research, 6(5): 244-247. 